Kong. Res. J. 1(1) : 1-3, 2014

Kongunadu Arts and Science College, Coimbatore

\title{
THE NEED OF SPIRITUAL ENDEAVOURS FOR AN INTELLECTUAL EXISTENCE: A RE-READING OF HERMANN HESSE'S SIDDHARTHA
}

\author{
Praseeda, M.K*. \\ Department of English, Kongunadu Arts and Science College, Coimbatore \\ *E.mail: praseedaraj@hotmail.com
}

\begin{abstract}
HermannHesse'sSiddhartha is focussed on the tribulations of Siddhartha through his quest for inner peace. His journey begins as a young Brahmin who yearned to unwind the complexities of his existence. He ends as an old sage who has found peace within himself and his surroundings. Through this novel Hesse, allows the readers to trace the maturation process both through his experiences and people with whom he comes to contact.Born of Protestant family in Germany he was tremendously influenced by ancient Hindu Philosophy. His search for Eastern mysticism can be seen in this novel. He could recognise the unity of vision in Hinduism and Buddhism. He could detect the essence of Indian spiritual life led by many people.Siddhartha, the protagonist of the novel, identify the path for attaining enlightenment and he goes in the way where he experiences the worldly life hurdles. He could understand that the enlightenment does not come from mastering either the material or spiritual world but from finding the common ground between these polarities of existence. Siddhartha finds enlightenment only when he understandsOm, the unity of polarities.
\end{abstract}

Keywords: Spiritual endeavours, Hermann Hesse's Siddhartha.

In an atmosphere of collective identity, ethical obligation and political responsibility by narrowing the diverse geographical spaces,a rereading of Hermann Hesse's fiction becomes significant. My paper intends to examine the philosophical implications in Hesse's Siddhartha which have inspired to relocate the divine in us. The phenomenon of globalisation has destabilised the prevailing concepts of cultural diversity and in such juncture the main concern is the constructive and meaningful efforts to resist spiritual degeneration .

Siddhartha is focussed on the tribulations of Siddhartha through his quest for inner peace. His journey begins as a young Brahmin who yearned to unwind the complexities of his existence. He ends as an old sage who has found peace within himself and his surroundings. Through this novel Hesse allows the readers to trace the maturation process both through his experiences and people with whom he comes to contact.

Hermann Hesse was born of Protestant family in Germany. A democrat in politics and an individualist in outlook, he confessed that he was tremendously influenced by ancient Hindu Philosophy. He was one of the most cultured and sensitive of contemporary German writers .His western upbringing and the conscious application of the intellect helped Hesse in discerning the spiritual greatness of Buddhism and Hinduism. He was much fascinated by the endless patience and kindness and this essence of experience, Hesse puts across to the western readers through the character of Siddhartha. He is a bundle of contradictions till he realises the multiplicity in appearances and the timelessness in this temporal life. Hesse became a quester, a seeker after truth. As every seeker he finally sees a unity in diversity. His search for truth also confirmed this strong conviction that mankind has a meaning. It must be remembered that without understanding the religious consciousness of India a novel like Siddhartha could not have been written. His friend and servant, Govinda, the ferry man, Kamala; the prostitute, Vasudeva , Kamaswamy; the merchant-all of them from various socio-structural patterns taught him the meaning of life. Even the river in the novel had something special to tell him. It was always the same yet every moment it was new. The river becomes to him the symbol of universal beauty, harmony and love.

Hermann Hesse the author of Siddhartha was very much influenced by the hidden spirit of India. Buddha's influence and and his search for religious serenity in Eastern mysticism can be seen in Siddhartha. Hesse's parents and grandparents had long connections with India. His grandfather came to India in 1836.Marie Hesse, his mother was born at Thalassery, in North Malabar. Gundert wrote the first Malayalam -English dictionary, the first Malayalam grammar book and had translated the Bible in to 
Malayalam. In Gundert's family Hinduism, Buddhism, Confucianism, and Protestantism, mingled without contradictions and this influenced the young mind of Hesse. He could recognize the unity of vision which is the essence of Indian life. His western upbringing and the conscious application of the intellect helped Hesse in discerning the spiritual greatness of Hinduism and Buddhism.

The story begins by painting a picture of Siddhartha as a perfect son: smart, athletic, obedient, and handsome. However, he eventually sees the limitations of the Brahmin life, and leaves his home to join the ascetics with his companion Govinda. The two set out in the search of enlightenment. After seeing the limitation of asceticism, the two journey to meet the Buddha. Govinda is immediately impressed and takes refuge in the Buddha. Siddhartha respects the Buddha's enlightenment, but realizes that no teaching, not even the Buddha's, can capture enlightenment.

The second half of the book starts with Siddhartha impressing a beautiful, wealthy courtesan. She sets him up with a job so that he can afford the beautiful things that will impress her. Initially seeing this as a game for children, he eventually finds himself caught up in the trading, drinking, and gambling of a merchant life. "Then Siddhartha knew the game was finished, that he could play it no longer. A shudder passed through his body" (Siddhartha,67). He leaves again for the forest. After settling into a nice life sharing ferryman duties with a wise friend, Siddhartha finds out him fathered a son. He attempts to raise the boy in this simple life, but the boy gets frustrated and returns to the city. Siddhartha finally feels the sorrow of love, which leads to a deep compassion for all of his fellow humans. With Vasudeva, his guide Siddhartha learns to listen the river and hear the holy 'Om'.

...all the voices ,all the yearnings, all the sorrows, all the pleasures....all of them together was the stream of events ,the music of life.(Siddhartha,107)

Siddhartha studies the river for many years, and Vasudeva teaches Siddhartha how to learn the many secrets the river has to tell. In contemplating the river, Siddhartha has a revelation: Just as the water of the river flows into the ocean and is returned by rain, all forms of life are interconnected in a cycle without beginning or end. Birth and death are all part of a timeless unity. Life and death, joy and sorrow, good and evil are all parts of the whole and are necessary to understand the meaning of life. By the time Siddhartha has learned all the river's lessons, Vasudeva announces that he is through with his life at the river. He retires into the forest, leaving Siddhartha to be the ferryman. He asserts his own belief in time and unity that brings him much closer to inner peace. He hears the universal within the $\mathrm{Om}$ and he understood that only love can bring peace to the world.

Experience is the aggregate of conscious events experienced by a human in life - it connotes participation, learning and knowledge. In Hesse's novel Siddhartha, experience is shown as the best way to approach understanding of reality to attain enlightenment. Hesse's crafting of Siddhartha's journey shows that understanding is attained not through scholastic, mind-dependent methods, nor through immersing oneself in asceticism and the carnal pleasures of the world. While these individual events only bring about more samsara, they cannot be considered distractions because it is the totality of these experiences that allow Siddhartha to attain understanding.

In Siddhartha, Siddhartha finds that enlightenment does not come from mastering either the material or spiritual world but from finding the common ground between these polarities of existence. In the first third of the book, Siddhartha rejects the material world. The Brahmins, Samanas, and Buddhists all maintain that the material world is illusion, or Maya, that distracts a seeker from the spiritual truth. Adopting this belief, Siddhartha completely denies his body and, instead, focuses his efforts on refining his mind and memorizing the knowledge his teachers pass along to him. In the second third of the book, Siddhartha rejects the spiritual world and enters the material world, but relentlessly pursuing carnal desire does not lead him to wisdom either. Siddhartha battles with other polar opposites as well, such as time/timelessness and attachment/detachment, but in these, too, he finds that embracing one and rejecting the other does not lead to enlightenment. The river suggests this battle visually: the opposing banks represent the polarities, and the river itself represents the ideal union of them. Siddhartha finds enlightenment only when he understands $\mathrm{Om}$, the unity of polarities. He achieves transcendence when he can accept that all is false and true at the same time, that all is living and dead at the same moment, and that all possibilities are united in the spirit of the universe

Siddhartha is often considered the high point of Hesse's art in fiction, as well as the pinnacle of his fascination with orientalism. The novella is concerned with the individual's search for truth and identity by means of what Hesse termed the inward journey, a recurring theme throughout his works. 
During that period, American youth, involved in an era of cultural upheaval, identified with the title character and his struggle to transcend meaninglessness and materialism through mysticism and love.

Hesse's Siddhartha reflects much of the literary and intellectual history of Germany and Western Europe during the first decades of the twentieth century. In particular, the work has many points in common with the Romantic Movement, neo-romanticism, and expressionism. The importance of what Hesse termed the individual's struggle to transcend the materialism of bourgeois society through art, mysticism, and love-is especially palpable in Siddhartha. Highly influenced by the philosophy of Friedrich Nietzsche, Hesse had vowed to reject traditional religion and morality and lead a life of individualism and isolation. Siddhartha also rejects traditional religion and morality, and ultimately finds that pure individualism is an embrace of unity, with love as the synthesizing agent. Thus, Siddhartha fits well both in the genres of the novel of education, and the Bildungsroman. Hesse addressed in Siddhartha, as in most of his other works, characters who struggle to come to terms with themselves, individuals who passionately attempt self-realization.

Hesse's literary creations are fictional attempts to counter vacuum born out of the cultural diversities of the world. Siddhartha is the sum total of ancient wisdom, Upanishadic wisdom and the very essence of the experience of the Buddha. It is the journey through the self, till one discovers the true place of one's self in this world of diversity and illusion. The author's ability to universalize private agony and personal crises, as demonstrated in Siddhartha, has allowed Hesse to achieve an ongoing international popularity. Siddhartha is a colourful novel about an Indian youth's long and spiritual quest for the answer to the enigma of man's role on earth.

\section{REFERENCES}

Hesse, Hermann. Siddhartha. Trans. Rosner, Hilda. 1951. NewYork: Bantam Books, 1971.

Casebeer, Edwin F. Siddhartha :AComplete Hero. Hermann Hesse. NewYork: Warner books, 1972. 